\title{
THE EDITORS' CORNER
}

The new editors will, from time to time, print notices of interest to the subscribers in this section.

On behalf of members of the profession, the Executive Committee, and the Advisory Board, the incoming editors wish to acknowledge with appreciation George Gibb's eight years (1954-1961) of distinguished service as editor of the Business History Review. George assumed the editorial direction of the Review during a critical period, and under his direction this periodical has made significant contributions to the academic and business communities. We join with other members of the profession in wishing George success in his new endeavors.

Continuing a tradition started during George's editorship, the Review reports in the following pages announcement of the Newcomen Awards for 1961 and notice of a new Australian journal devoted to the history of business enterprise.

In connection with the editors' plans to develop the Review into an international publication, correspondents are being established throughout the world to report on developments in business history. We shall publish these contributions periodically in future issues of the magazine. 


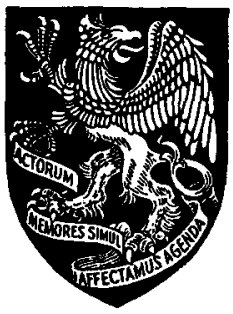

\title{
Newcomen Awards \\ in Business History
}

Presented by

THE NEWCOMEN SOCIETY IN NORTH AMERICA

\author{
in cooperation with
}

\section{THE BUSINESS HISTORY REVIEW}

\begin{abstract}
a Two Newcomen Awards in Business History are presented annually for articles published in the Business History Review. The First Prize, of $\$ 250$, is awarded the article judged, according to the rules outlined below, to be the best of the year. The Special Award, of $\$ 100$, is for the best article submitted by an author not more than 35 years of age and who has not published a book.
\end{abstract}

a Prize articles are selected by a panel of judges composed of a representative of The Newcomen Society and selected members of the Advisory Board of the Business History Review. No member of the Advisory Board or editorial staff shall be eligible for a prize, and articles so authored will not be considered in the judging. Authors eligible for the Special Award shall also be eligible for the First Prize, but in no event shall both prizes be awarded for the same article. The Advisory Board reserves the right to withhold the Special Award in the event that eligible articles do not, in the Board's judgment, merit prize consideration. The awards program is administered by the editorial offices of the magazine.

a Criteria for selection include: originality, value, breadth, and interest of contribution, quality of research materials and methods, and quality of presentation.

I Announcement of the 1961 awards was made at The Newcomen Society Dinner on January 18, 1962, at the Hotel Pierre in New York City. 


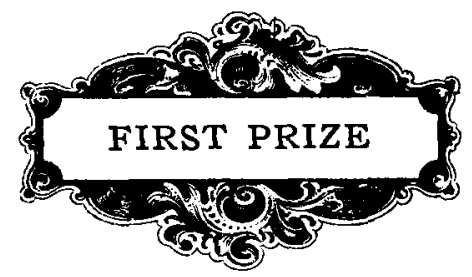

\author{
Mabel Newcomer \\ PROFESSOR EMERITUS OF ECONOMICS \\ VASSAR COLLEGE
}

\title{
The Little Businessman: \\ A Study of Business Proprietors in Poughkeepsie, New York
}

I This cross-sectional study of small business tests conventional assumptions regarding backgrounds, motivation, characteristics, function, risks, and longevity, proving many of those assumptions to be imprecise or false. Quantification in historical depth reveals definite patterns both of fixity and change.

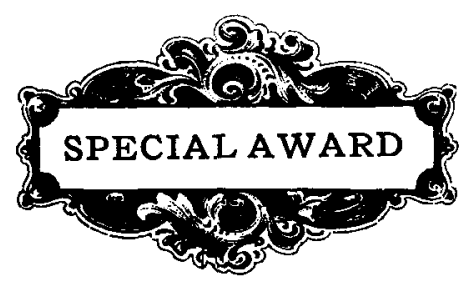

\section{Frederick J. Glover}

FULBRIGHT VISITING ASSOCIATE PROFESSOR OF ECONOMICS

THE COLLEGE OF WILLIAM AND MARY

\section{Thomas Cook \\ and the American Blanket Trade in the Nineteenth Century}

a Dominance of the American blanket trade was obtained and held for half a century through a combination of aggressive marketing, progressive manufacturing methods, and far-sighted administration of a business beset by constant difficulties, part of which were peculiar to the times; part familiar to business in every age and circumstance. 


\section{BUSINESS ARCHIVES AND HISTORY}

There is a new publication called Business Archives and History, published by The Business Archives Council of Australia, with headquarters at The University of Sydney, Dr. Alan Birch, Editor. This is published twice yearly, in February and August, and will include contributions from accountants, archivists, business executives, and business and economic historians on the many topics that impinge on business enterprise.

This journal is a successor to the Bulletin of The Business Archives Council. The first number was issued in February, 1962, and contained articles from American and Australian scholars.

Manuscripts and editorial communications should be addressed to Dr. Alan Birch, Editor, Faculty of Economics, University of Sydney, Sydney, N.S.W., Australia. 